\title{
CHRZEŚCIJAŃSKIE DOŚWIADCZENIE DUCHOWE SŁUGI BOŻEJ S. LEONII NASTAŁ
}

W nauczaniu teologicznym chrześcijańskie doświadczenie duchowe jest aktem lub sumą aktów, za pomocą których człowiek ujmuje siebie w relacji do objawiającego się Boga. W odróżnieniu od ogólnie pojętego doświadczenia religijnego, chrześcijańskie doświadczenie duchowe aktualizuje się przez Chrystusa w Kościele. Dlatego też sakramentalna komunia z Chrystusem jest podstawą chrześcijańskiego doświadczenia duchowego. Doświadczenie to ma charakter indywidualny, jednak zawsze posiada też wymiar eklezjalno-wspólnotowy.

Siostra Leonia Nastał ${ }^{1}$ przez dar kontemplacji pośród codziennych zwyczajnych zajęć odkryła prawdę o kochającym Bogu. W sposób szczególny doświadczyła Jego miłości i zjednoczenia z Nim. Aby osiągnąć ten stan ducha, należy przyjąć własną małość, ułomność, ale jednocześnie w pełni zaufać Bogu, pokornie zatapiając się w Jego miłości. Takie doświadczenie duchowe zdaniem s. Leonii prowadzi do niemowlęctwa duchowego.

Siostra Nastał jest polską mistyczką. Na polecenie spowiednika ks. Kazimierza Schmelzera spisywała w latach 1934-1939 swoje przeżycia duchowe, pozosta-

* Ks. Stanisław Suwiński, doktor teologii, adiunkt w Zakładzie Teologii Duchowości Wydziału Teologicznego Uniwersytetu Mikołaja Kopernika.

${ }^{1}$ Służebnica Boża Leonia Maria Nastał urodziła się 8 listopada 1903 r. w Starej Wsi koło Brzozowa, gdzie znajduje się Dom Generalny Zgromadzenia Sióstr Służebniczek NMP. Do zgromadzenia wstąpiła w 1925 r. Gruźlica spowodowała jej szybką śmierć w 1940 roku. 
wiając po sobie osiem zeszytów, które dziś są nazwane „Dziennikiem duchowym”. Zachowały się też 352 listy, jednak do druku oddano tylko te, które mają ścisły związek z "Dziennikiem duchowym” lub obrazują życie duchowe Służebnicy Bożej. „Dziennik duchowy” i „Listy” stanowią cenny dar dla tych, którzy poszukują drogi do nieba, realizując swe powołanie w doświadczeniu chrześcijańskim.

\section{DOŚWIADCZENIE OBJAWIAJĄCEGO SIĘ BOGA OJCA}

Bóg Ojciec objawia swą moc w akcie stwórczym, powołując do życie świat i wszelkie istnienia. Odwieczną miłością obdarzył jedynie człowieka, dając mu uczestnictwo w życiu wiecznym. Siostra Leonia o stworzeniu człowieka mówi, że jest on jak „mała iskierka”, która staje się blaskiem miłującego Ojca². Bóg jest Stwórcą ciała i duszy, ale przede wszystkim jest dawcą życia nadprzyrodzonego. Człowiek jednak nie zastanawia się nad tym. Gdyby zastanowił się nad wartością duszy, to według s. Nastał byłby bardziej skłonny do miłości. Dusza ludzka to dzieło wszechmocy, mądrości i miłości Bożej. Toteż bolesną rzeczą jest widzieć człowieka, który jest owocem miłości Bożej do stworzenia, jak "tarza się on w błocie"

Bóg jawiący się w pismach s. Nastał jest ukojeniem i podporą dla duszy człowieka. Podkreślana jest tu miłość Ojca Niebieskiego do człowieka. Siostra Leonia z afektem opisuje doświadczenie miłości Ojca, o czym świadczą słowa:

Ulgę przynosiły mi tylko myśli o Ojcu niebieskim, w którego obecności tak się dobrze dawniej czułam. Raz, nawet wśród opuszczenia, szepnął do duszy: jestem w twojej duszy - nie bój się. A innym razem kiedy się lękałam, czy moje ofiary nie są narzucaniem się tylko - szepnął: z mojej strony nie masz się czego obawiać [...] Pomimo twej małości nie zginiesz we mnie bez śladu, choć jestem ogniem wszystko pochłaniającym, ale błyszczeć będziesz przez wieczność całą ${ }^{4}$.

Ojciec objawia miłość w swym Synu i przez Syna. Sługa Boża dostrzega to $\mathrm{w}$ doświadczeniu wewnętrznym, gdyż powiedział jej o tym Chrystus. On odkrywa przed duszami ludzkimi tajemnice miłości Ojca. Tylko dusze o czystym sercu są w stanie te tajemnice poznawać i zgłębiać ${ }^{5}$.

${ }^{2}$ Zob. S. Leonia Nastał, Uwierzyłam Miłości. Dziennik duchowy. Wybór listów, Stara Wieś 2000, s. 50 (odtąd DD).

${ }^{3}$ Zob. DD, s. 90-91.

${ }^{4}$ DD, s. 50; zob. E. Korobij, Doświadczenie ojcowskiej mitości Boga drogq do świętości stużebnicy Bożej s. Leonii Marii Nastat, w: Święci, błogostawieni, świadkowie wiary Archidiecezji Przemyskiej. Materiaty z sesji naukowej, Krosno 2001, s. 188-203.

${ }^{5}$ Zob. DD, s. 101. 
Siostra Leonia została powołana przez Boga, była Jego umiłowaną uczennicą i w sposób szczególny obdarowaną łaskami. Jezus pouczył ją, w jaki sposób ma kształtować w sobie postawę uczennicy:

powtarzaj Ojcu niebieskiemu: Z Panem Jezusem uwielbiam Cię Ojcze; Z Panem Jezusem kocham; Z Panem Jezusem dziękuję Ci za odebrane łaski; Z Panem Jezusem żyję dla Twojej chwały. Możesz tak mówić dlatego, że istotnie żyję w twojej duszy, choć tego nie odczuwasz, a wiedz, że nie jestem tam bezczynny ${ }^{6}$.

Życie z Jezusem jest życiem dla Ojca niebieskiego, to dla Niego Leonia uznaje swą nicość i grzeszność, uznając siebie za robaczka maleńkiego, buntowniczego i grzesznego. Ten robaczek maleńki przez posiadanie duszy nieśmiertelnej, jest jej droższy niż cały wszechświat materialny ${ }^{7}$.

Bóg Ojciec i Syn Boży stanowią jedność wraz z Duchem Świętym. Dlatego wszystko, co dotyka Ojca, na równi dotyka również Jego Syna. Miłość ku Ojcu jest darem Ducha Świętego. Kontemplacja Trójcy Świętej jest zatem doświadczeniem pełni miłości Boga. Siostra Leonia pisze, że „Dusza moja oglądała Boga w jasnym widzeniu. Majestat Jego nieskończony oglądałam tak, jak widzi samego siebie Bóg, bo jest Bogiem. Widziałam świętość i majestat Boga, posunięte aż do nieskończoności"s.

Pełnią objawienia miłości Ojca jest Jego Syn, który daje świadectwo swego posłania na świat i przez własne cierpienie nadaje szczególną wartość miłości:

Cierpiałem nad zniewagą wyrządzoną Bogu, cierpiałem aż do nieskończoności nad zniewagą wyrządzoną Ojcu mojemu. Był to ból, którego nie mogło pomieścić moje Serce, więc krew najświętsza wypłynęła z niego, wypłynęła z żył. [...] Ogromu moich cierpień nikt nie zmierzy, bo ja cierpiałem za wszystkich i za każdego z osobna. Łącz się ze mną w moich cierpieniach, ofiaruj ojcu niebieskiemu moje ukryte cierpienia - za ukryte grzechy, które ranią moje Serce'.

Siostra Nastał otrzymała polecenie od Jezusa, aby miłość Ojca do stworzenia była przedmiotem jej poniedziałkowej modlitwy ${ }^{10}$. Treścią tej modlitwy winna być wdzięczność: „Dziękuj Ojcu przedwiecznemu za to, że raczył dać ludzkości swego Syna. Dziękuj Słowu, że raczyło przyoblec na siebie ludzkie

\footnotetext{
${ }^{6}$ Tamże, s. 80.

${ }^{7}$ Zob. tamże, s. 90-91.

${ }^{8}$ Tamże, s. 136-138.

${ }^{9}$ Tamże.

${ }^{10}$ Zob. tamże, s. 111.
} 
ciało, dziękuj Duchowi świętemu, że przysposobił to ciało z krwi dziewicy Niepokalanej"11.

\section{DOŚWIADCZENIE CHRYSTUSA PRZEZ NIEMOWLĘCTWO DUCHOWE}

Chrystus uczy miłości Ojca i prowadzi do niej przez drogę niemowlęctwa duchowego, nazywając tę drogę „najkrótszą ku niebu drożyną" ${ }^{12}$. Jest ona dostępna wszystkim ludziom, gdyż jest zejściem o jeden stopień niżej niż droga dziecięctwa duchowego $^{13}$. Chrystusa poucza siostrę Leonię, że zstępowanie polega na pokonywaniu pychy i wysokiego mniemania o sobie, dlatego trzeba „zstępować ze szczytu urojonej wielkości, w niziny pokory i zapomnienia o sobie"14.

Niemowlęctwo duchowe jest pewnego rodzaju szkołą, w której dusze jak niemowlęta uczą się miłować Jezusa i podążać za jego wskazaniami. W tej szkole najistotniejszym zadaniem jest "kochać Jezusa coraz więcej i coraz goręcej”"15. Dlatego rozwój życia duchowego w tajemnicy niemowlęctwa jest zrozumiały w znaczeniu brania krzyża zadań i obowiązków oraz pokonywania ich przez zaparcie się siebie ${ }^{16}$. W jednym $\mathrm{z}$ listów siostra Leonia wyjaśnia, jak można pogodzić niemowlęctwo z doskonałością męża dojrzałego? Twierdzi, że dokonując na tym świecie wielkich czynów, można pozostać małym niemowlęciem. Tak też nauczał Jezus, kiedy mówił, że jeśli się nie staniemy jak dzieci, nie wejdziemy do królestwa niebieskiego (por. Mt 18, 3). Siła niemowlęctwa tkwi w doskonałości, gdyż maleńkim można zawsze pozostać, zwłaszcza wtedy, gdy czyni się wolę Ojca. W niemowlęctwie tkwi bohaterstwo i wzór dla ludzi dojrzałych. To właśnie postawę dziecka jako ów wzór doskonałości postawił

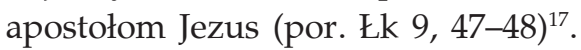

Jezusowi Chrystusowi zależy na duszach ludzkich. Walczy o duszę człowieka, by móc go obdarować szczęściem, a jednocześnie wychwalać czystość jego duszy przed Ojcem. Siostra Leonia uważa, że Jezus pragnie zawierać przyjaźń z duszami, przyjaźń serdeczną i zażyłą: „Takimi duszami chlubię się przed Ojcem niebieskim i przed dworzanami moimi, że mam na świecie dusze, które dla mnie niczego nie żałują - ni trudów, ni ofiar; gotowe są nawet życie

${ }^{11}$ Tamże, s. 122.

${ }^{12}$ Tamże, s. 57; 58.

${ }^{13}$ Zob. List do ks. Franciszka Chromika SJ, 6.04.1936, w: DD, s. 496.

${ }^{14} \mathrm{DD}, \mathrm{s} .58$.

${ }^{15}$ Tamże, s. 90.

${ }^{16}$ Zob. tamże, s. 118; 189.

${ }^{17}$ Zob. List do ks. Franciszka Chromika SJ, 23.08.1936, w: DD, s. 503; B. Pasterak, Niemowlęctwo duchowe jako charakterystyczny rys duchowości s. Leonii Marii Nastat Stużebniczki NMP Niepokalanie Poczętej, Kraków 1999, s. 39; B. Lipian, Droga niemowlęctwa duchowego s. Leonii Nastat, "Communio", rok V, nr 3 (27), s. 95-106. 
poświęcić dla Mnie. Światu, lecącemu na oślep w przepaść zguby, potrzeba takich dusz, które by składając z siebie całopalną ofiarę, powstrzymywały go w jego zawrotnym pędzie w przepaściste otchłanie"18.

Siostra Leonia podkreśla, że powołaniem chrześcijanina jest kształtowanie w sobie postawy niemowlęcia duchowego, gdyż w ten sposób uformuje on w sobie serce wolne od niechęci do bliźniego. Jezus poucza ją słowami: „miłość Ojca przedwiecznego i miłość wszystkich ludzi były treścią mojego życia niemowlęce-

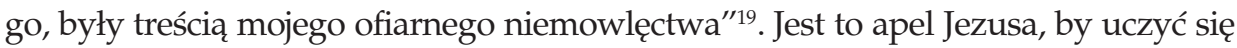
doskonałej miłości bliźniego, składania z siebie cichej ofiary tak, by nikt, gdy tego wymaga chwała Boża, o tym nie wiedział. Bóg bowiem dał ludziom przykazanie, by kochali się Bożą miłością. Dla Sługi Bożej praktykowanie czynnej miłości bliźniego jest odpowiedzią na Jezusowe słowa: „byłem głodny, a nie nakarmiliście Mnie" (Mt 25, 35-44). Jezus ma na uwadze ludzi głodnych i samego siebie, czemu daje wyraźne wskazanie również w słowach: „żyję w moich bliźnich. Kto im przychodzi z pomocą, Mnie samemu przysługę oddaje"20.

Pan Jezus wyznaczył siostrze Leonii misję, która nie polegała na ewangelizowaniu w dalekich krajach, ale na spisywaniu tego, co do niej mówi i świadczeniu swym pokornym życiem o Jego obecności w świecie. Podstawą w świadczeniu o Nim w świecie ma być zjednoczenie z Nim:

Żyć we Mnie - to czynić wszystko dla Ojca, uwielbiać Go, miłować już nie własnym tylko wysiłkiem, ale zjednoczeniem swej maleńkości z miłością Jezusową. [...] Żyć we Mnie - to razem ze Mną wyniszczać się na ołtarzu, stać się ofiarą i ofiarnikiem ku chwale Ojca i za zbawienie świata ${ }^{21}$.

Misja w świecie powinna wyrażać przede wszystkim to, że Pan Jezus pragnie dotrzeć do każdej duszy ludzkiej. Jednak przeszkody życia codziennego, zbytnie zajmowanie się sprawami doczesnymi, nie pozwalają na łączenie się z Jezusem:

"Jest wiele dusz, które oddają się pracy całkowicie, wszystkie swoje zdolności i czas oddają tylko pracy, a nie mają jednej chwili na to, by się zwrócić do Mnie bodaj z jednym serdecznym westchnieniem. Ja jednym słowem stwarzam światy, a licznymi zabiegami nie mogę zdobyć jednego aktu miłości od duszy rozproszonej i wylanej na zewnątrz"22.

${ }^{18} \mathrm{DD}$, s. 96.

${ }^{19}$ Tamże, s. 81; Zob. List do ks. Franciszka Chromika SJ, 30.07.1936, w: DD, s. $500-501$.

${ }^{20}$ DD, s. 192; por. List do s. Józefy Piekarz, 17.03.1938, w: DD, s. 539.

${ }^{21}$ DD, s. 110.

${ }^{22}$ Tamże, s. 72. 
Według siostry Nastał czyny miłości bliźniego pozbawione miłości Jezusa mają niewielkie znaczenie. Mogą być tylko czymś pozornym, zewnętrznym przypodobaniem się ludziom, dla własnego rozgłosu. Takie akty miłości nie dają pożytku duszy, ale są raczej tymi, które upodabniają do tych, „którzy, nie znając wartości banknotów, wymieniają je za bezcen”23. Toteż miłość bliźniego dla s. Leonii na drodze niemowlęctwa duchowego jest powinnością i obowiązkiem o charakterze powszechnym. Każdy człowiek jest podmiotem w miłości Boga i kochać go należy ze względu na Boga ${ }^{24}$.

\section{PRZYMIOTY BOŻE W DOŚWIADCZENIU DUCHOWYM}

Na doświadczenie chrześcijańskie mają duży wpływ przymioty Boga. Przez nie Bóg objawia się stworzeniom i dzięki nim człowiek ujmuje siebie w relacji do Boga. W doświadczeniu Boga, jakie szkicuje w swych pismach s. Leonia, dostrzega się kilka podstawowych Bożych przymiotów. Należą do nich: dobroć, sprawiedliwość, miłosierdzie, świętość i wszechmoc.

\section{A) DOBROĆ BOGA}

W życiu dobrocią można nazwać sposób postępowania wypływający z miłości, a cechujący się życzliwością i przychylnością. Człowiek zachowujący przykazania, kierujący się miłością zawsze jest obiektywnie dobry.

Dobroć Boga, której doświadczyła s. Nastał wyraża się w tym, że Bóg powołał ją do odkrywania dobra w stworzeniach. Bóg jest jedynym źródłem dobra i wszystko, co powołał do istnienia, zachowuje ze względu na dobro ${ }^{25}$.

Boża dobroć powinna być dla człowieka gwarancją jego życia w przyszłości. Bóg jest dobry, więc nie skrzywdzi tych, których ukochał: „Dziecino moja, nie myśl o przeszłości - powierz ją zupełnie miłosierdziu Bożemu; Nie myśl o przyszłości - powierz ją całkowicie dobroci Bożej”26. Siostra Leonia porównuje dobroć Boga do matki, która zawsze się opiekuje swoim dzieckiem. Kocha je nawet wtedy, kiedy ono zbłądzi. Jest gotowa przynieść na rękach okaleczone dziecko, opiekować się nim, nie szczędząc troski i kosztów, aby je wyleczyć. Siostra Leonia stwierdza, że dobroć Boga idzie jeszcze dalej, bo nawet w sytuacji, w której matka wyrzekłaby się swojego dziecka, dlatego że postąpiło ono karygodnie, Bóg nie wyrzeknie się tego, którego umiłował dobrocią nieogarnioną ${ }^{27}$.

23 Tamże, s. 5

${ }^{24}$ Zob. List do s. Lucjany Grochmal, 6.03.1938, w: DD, s. 543.

${ }^{25}$ Zob. DD, s. 104.

${ }^{26}$ Tamże, s. 178.

27 Zob. tamże, s. 178. 
Dobroć Boga jest zaszczepiona w serce każdego człowieka, jest też dla niego wezwaniem do dzielenia się dobrem, zwłaszcza odkrywanym w Słowie Bożym:

Moja dobroć jednak w różnym czasie, w różny sposób, rozjaśnia poszczególne prawdy, by przez nie przemówić czulej i serdeczniej, z bliska niejako, a nie przez odległość wieków, jak się to niektórym duszom wydaje, gdy słuchają Słowa Bożego, głoszonego przez kapłanów. Tymczasem ja jestem tuż, jestem w Kościele aż do skończenia świata. Ażeby zaś jeszcze bardziej zbliżyć się do dusz, przemawiam niekiedy przez dusze proste - by uznały moją bliskość i miłość przyjacielską ${ }^{28}$.

Dobroć Boga jest także przedmiotem działań Jego Syna. Został On nazwany Nauczycielem Dobrym przez bogatego młodzieńca (por. Mt 19, 17). Dobro, jakim promieniował Jezus, prowokowało niektórych ludzi do stawiania pytań o sens życia. W pismach s. Leonii napotykamy na alegorię ukazującą Jezusa jako artystę, który oczyszcza człowieka, niczym zapomniany czy zakurzony obraz, uzupełnia w nim braki po to, by jak najbardziej upodobnić go do obrazu Boga. Alegoria nawiązuje do treści Ewangelii, gdzie czytamy, że Jezus przyszedł, by uleczyć, pocieszyć, ocalić i zbawić człowieka. W ten sposób pokazuje, że dba o los ludzi, troszczy się o nich i nikogo nie odtrąca, a zwłaszcza tych, których odtrąca świat ${ }^{29}$.

Siostra Nastał posługuje się jeszcze innym obrazem ukazującym dobroć Boga. Jest to postać Chrystusa-zegarmistrza, który naprawia zepsute zegary. Mistyczka uważa, że tak jak zegarmistrz zna się na zegarach i wszystkich jego detalach, tak tym bardziej Pan Bóg, który jest Stwórcą człowieka, zna go w całości i jest w stanie naprawić w nim wszystko to, co zepsuł grzech. Jedyne, czego potrzebuje Bóg od człowieka, to uznania swego błędu, czyli zauważenia swojej grzeszności i bezsilności oraz swobody działania. Bóg chce nas zbawić, obdarować szczęściem, którego ma w nadmiarze: „Ach, komu Ja dam to, co wypływa z mego Serca - to dobro bez końca? [...] Dla wszystkich starczy, byleby chcieli przyjmować" 30 .

Według siostry Leonii na szczególną uwagę zasługuje dobroć Boga objawiająca się w Eucharystii. Pisze ona: „Bóg jest dobry, gdyż takie cuda czyni dla uszczęśliwienia swego małego stworzenia"31. Dar Najświętszego Sakramentu wskazuje na pełnię dobroci Boga, gdyż w niej jest zawarta miłość, ofiara i zabawienie:

\footnotetext{
${ }^{28}$ Tamże, s. 107.

${ }^{29}$ Zob. tamże, s. 105.

${ }^{30}$ Tamże, s. 196.

${ }^{31}$ Tamże, s. 240.
} 
W żadnym udzielaniu się Boga na zewnątrz [...] nie oddaje się Bóg tak stworzeniu, jak w Komunii św. Bóg tak jest zajęty duszą, która się zbliża do ołtarza dla przyjęcia Najświętszej Eucharystii, że zdaje się zapominać o całym wszechświecie, bo ma dokonać największego cudu wszechmocy, miłości i miłosierdzia ${ }^{32}$.

\section{B) SPRAWIEDLIWOŚĆ BOGA}

Siostra Leonia podkreśla, że obok dobroci Boga również Jego sprawiedliwość oddziałuje na życie ludzkie. Powołaniem chrześcijanina jest postępowanie według Bożej sprawiedliwości i sprawienie, by mogła ona objawić się w świecie. Bóg objawia się przede wszystkim jako Miłość, ale człowiek poznaje także Jego sprawiedliwość. Sługa Boża pisze:

Sprawiedliwość jest jak wszystko trawiący ogień. W tej chwili z jednego ogniska, pełnego jasności, zaczęła się wylewać lawina ognia, który niszczył wszystko, co napotkał na drodze. To jest moja, karząca nieprawości świata, sprawiedliwość - rzekł Bóg. Wszystko zgładzę, bo wszystkich moich stworzeń nadużywa człowiek [...] pragnęłam tylko za wszelką cenę zatrzymać tę lawinę. [...] Na niej wywrę moją sprawiedliwość. Córkę swoją sprawiedliwością chłostać będziesz? Tak uczyniłem z moim najmilszym Synem - Jezusem ${ }^{33}$.

\section{C) MIŁOSIERDZIE BOGA}

Bóg jest dobry i sprawiedliwy, jednak nad sprawiedliwością góruje Boże miłosierdzie, do którego odwołuje się s. Nastał. Ten przymiot Boga ważny jest w stosunku do grzeszników, gdyż w miłosierdziu objawia się moc Bożego oczyszczenia i Boża sprawiedliwość. O miłosierdzie należy prosić Boga w modlitwie: „uczynić to krótkim aktem: uwielbiam Cię, Jezu, i przepraszam za klątwy moich braci" ${ }^{34}$. Również akt wynagradzania za grzechy jest wybłaganiem Bożego miłosierdzia i ocaleniem przed potępieniem ${ }^{35}$.

Boże miłosierdzie może napotkać na zatwardziałe ludzkie serce. Siostra Leonia pisze, że każdy chrześcijanin winien przez modlitwę za zatwardziałych grzeszników oszczędzić im cierpień duszy, ale również sam musi oddalać się od zatwardziałości serca: „prosiłam Pana Jezusa, by ratował od tego nieszczę-

\footnotetext{
32 Tamże, s. 163.

33 Tamże, s. 278.

${ }^{34}$ Tamże, s. 60.

${ }^{35}$ Zob. tamże, s. 325-326.
} 
ścia, bym miała kiedykolwiek w życiu obrazić Go dobrowolnie - nie dlatego, że piekło straszne, lecz dlatego, że Bóg jest nieskończenie święty"36.

\section{E) ŚWIĘTOŚĆ BOGA}

Świętość Boga siostra Leonia ukazuje jako przymiot Boga włączony w Jego naturę, gdyż Bóg jest święty, czyli Jego natura jest bez grzechu:

jest samą świętością. Źrenica oka ludzkiego jest tak delikatna, że skoro wpadnie do niej bodaj drobny pyłek, zalewa się łzami, aż wyrzuci z siebie obce ciało. Tak Bóg - nieskończona Świętość - nie może znieść w sobie tego, co jest mu obce, a tym jest grzech. Bóg i grzech nigdy ze sobą współistnieć nie mogą ${ }^{37}$. Bóg w swojej świętości nie znosi niczego, co plami duszę ${ }^{38}$.

Sługa Boża Leonia uważa, że grzech nie może przekreślić szansy człowieka na święte życie. Człowiek winien zawsze swe serce, w sposób wolny od wszelkiego zła, kierować ku świętości Boga. Pod datą 30 sierpnia 1936 roku s. Nastał zapisała słowa, w których, prowadząc rozmowę z Jezusem, wykazywała niepokój duszy, powodowany świadomością grzeszności. Jezus objawia Leonii swe nieskończone pragnienie świętości człowieka, wychodzi naprzeciw jego grzeszności, by go zapewnić o Swej pomocy:

gotów jestem przyjść w taki sam jawny i poufały sposób, jak do ciebie, do każdej duszy - nawet do takiej, która popełniała największe grzechy, byleby tylko ukochała mnie więcej niż letnią miłością, byle Mi zaufała, że jako dobroć nieskończona nie mogę pamiętać niewierności duszy i na jedno tylko oczekuję - na całkowite oddanie się, na pełnienie woli mojej, na ufność, pokorę, a nade wszystko na dziecięcą miłośćc ${ }^{9}$.

Bóg jest zawsze wierny swojej obietnicy i kiedy s. Nastał wyznaje, że duszę ma zatopioną w Bogu, to dostrzega, że ten stan świętości jest owocem czystego serca. Powołaniem każdego człowieka jest nieustanne odkrywanie w sobie podobieństwa do Boga i do Jego świętości. Celem życia chrześcijańskiego jest zatem oglądanie Boga, a dokonuje się ono drogą osobistego uświęcenie przez czystość serca:

Błogosławieni czystego serca, albowiem oni Boga oglądają. Dusze czyste oczyma umysłu swojego wpatrują się w Jezusa - słowo żyjące na łonie

\footnotetext{
36 Tamże, s. 359.

${ }^{37}$ Tamże, s. 126.

${ }^{38}$ Zob. tamże, s. 251.

${ }^{39}$ Tamże, s. 283.
} 
Ojca niebieskiego. Oglądają pełną tajemnych mroków, niezgłębioną Trójcę przenajświętszą w wierze żywej, w kontemplacji pełnej upojenia"40.

W innym miejscu Sługa Boża dodaje, że Bóg tych, którzy dochowują Mu wierności, nie pozostawi, a odwiecznym Jego pragnieniem jest widzieć wszystkich przed swym obliczem: „Wierny jest Bóg w obietnicach swoich, najgorętszym Jego pragnieniem jest widzieć wierność swoich dzieci" ${ }^{41}$.

\section{F) WSZECHMOC BOGA}

Wszechmoc Boga objawia się nie tylko w stworzeniu świata, który powstał z nicości. Przejawem Jego wszechmocy jest także Opatrzność oraz dzieło odkupienia i uświęcenia człowieka. Ujawnia się również w odpuszczeniu grzechów i w przywracaniu łaski uświęcającej, toteż przez przebaczenie i litość najpełniej Bóg okazuje swoją wszechmoc. Siostra Nastał podkreśla dzieło wszechmocy Bożej wobec serca człowieka:

Wiedz jednak, że daleko więcej uwydatnia się moja wszechmoc w stwarzaniu w duszy cudów łaski. Każde posunięcie duszy na drodze doskonałości, każde pomnożenie w niej miłości jest cudem wszechmocy Bożej. Wobec sił duszy nabytych $\mathrm{w}$ tym zespoleniu $\mathrm{z}$ Bogiem słabnie mocarna potęga gromów. Tych cudów wszechmocy dokonuję ustawicznie w duszy, w miarę jej wierności i zaufania ${ }^{42}$.

Sługa Boża Nastał uznaje stan duszy pełen nicości i pokory wobec Bożego działania. Człowiek jest tym bardziej oddany Bogu, im trudniej osiąga ten stan w duszy: „Czułam, że zetknięcie się nicości z Wszechmocą potrafi uzyskać o co prosi, gdy prosi z ufnością dziecka, apelując do nieskończonej dobroci, zwłaszcza gdy ta nicość przychodzi z miłością ofiarną, bo wówczas miłość Boga zaznacza się również ofiarą względem maleńkiej duszy." ${ }^{43}$

\section{DOŚWIADCZENIE DUCHOWE W KOŚCIELE}

Eklezjalny wymiar chrześcijańskiego doświadczenia duchowego oznacza, że Kościół jest podmiotem w tym doświadczeniu, gdyż wiara w Kościół święty należy do prawd dogmatycznych. Kościół, jako Mistyczne Ciało Chrystusa, jest źródłem rozwoju życia chrześcijanina i pozwala mu na komunię z Głową Kościoła, czyli z Chrystusem. Siostra Nastał uważa, że wszyscy są cząstką Ciała

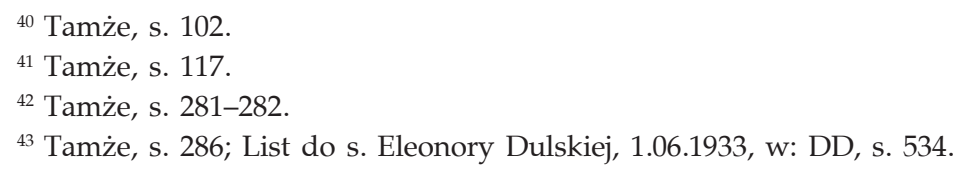


Mistycznego i czują to w sobie dzięki łasce Bożej, która ożywia w każdym świadomość doświadczenia Boga w sobie ${ }^{44}$.

Nieodłącznym aspektem związanym z doświadczeniem duchowym w Kościele, według siostry Leonii, jest poznawanie i doświadczanie daru łaski Bożej. Łaska jest udzielona każdemu według określanego przez Boga planu. Bóg daje ją zwłaszcza temu, kto o nią prosi. Jezus wyznaje s. Leonii, że Jego łaski są potrzebne człowiekowi przede wszystkim do rozwoju miłości do bliźniego:

Łaski Boże otrzymujesz nie dla siebie, ale dla drugich, dla dobra dusz przeze mnie umiłowanych, którym przez ciebie chcę powiedzieć, że je kocham, że dla nich kryję w swoim Sercu łaski, które mogą odbierać w każdej chwili, byleby tylko z ufnością przychodziły czerpać ze zdrojów Zbawicielowych $^{45}$.

Łaska Boża jest wielką tajemnica, której nie sposób pojąć bez Bożej pomocy. Jest ona darem darmo danym, dzięki któremu jest możliwe zbliżenie się do Boga. Siostra Nastał podkreśla, że dusza ludzka winna być otwarta i zawsze gotowa na przyjęcie łaski, by „wyrzuciła ze serca wszelkie opieranie się działaniu łaski. Niech nie stawia żadnego oporu; niech pozwala łasce uczynić z niej, co chce, a łaska dokona uświęcenia"46.

Istota i głębia działania łaski Bożej wyraża się przez uczestnictwo w zasługach boskiego niemowlęctwa, przez ofiarność oraz przez uznanie w duszy własnej małości. Sługa Boża podkreśla, że

Kto bez tego kwitu przychodzi do Boskiej skarbnicy łask, niczego nie uzyska. Bo i czegóż mógłby się spodziewać bogacz, ubrany w bisiory, opływający we wszystko, dumny i pełen pogardy dla jałmużnika i jałmużny? Pokwitowanie musi być zaopatrzone pieczęcią, by mogło mieć wartość ${ }^{47}$.

Dalej s. Leonia określa wartość łaski w doświadczeniu duchowym, odwołując się najpierw do jej nadprzyrodzoności. Łaska jest życiem Bożym w duszy człowieka. Dlatego tylko Bóg zna cenę i wielkość łaski w całej pełni, „tylko Bóg, który jej udziela, otwiera niejako swe Boskie łono, by duszę napełnić Boskim życiem. Kto więcej Boga miłuje, więcej w tę łaskę obfituje" ${ }^{\prime 48}$.

Sługa Boża Nastał pisze o aktualizacji doświadczenia duchowego w Kościele, która dokonuje się przez Eucharystię. Eucharystia stanowi bowiem o żywotności Chrystusa w Kościele, a sakramentalna komunia z Nim jest podstawą

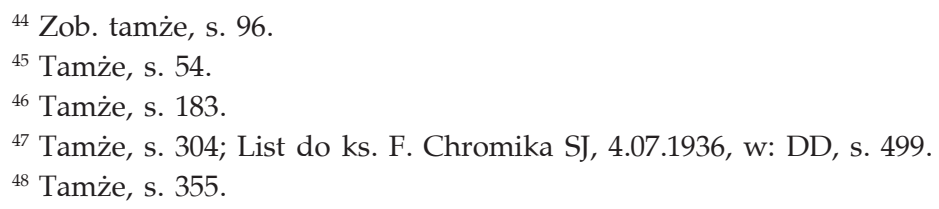


duchowego doświadczenia. Siostra Leonia słyszy od Jezusa o Tajemnicy Miłości, którą jest Eucharystia, z miłości bowiem do każdego człowieka Jezus ofiarował siebie Ojcu Niebieskiemu. Jego ofiara miłości obejmuje wszystkich tych, którzy poznali Go, którzy Go odrzucili, i tych, którzy Go jeszcze nadal szukają ${ }^{49}$. Aktualizacja doświadczenia duchowego jest także codzienną tajemnicą wiekuistego rodzenia Syna Bożego, odnowieniem Jego tajemnicy wcielenia, śmierci i zmartwychwstania. Dlatego wartość Eucharystii jest nieskończona ze względu na dobro i korzyść dusz, które zawsze mogą w Niej spotkać tego samego Jezusa, który w Wieczerniku wypowiadał słowa "to jest Ciało moje”, „to jest Krew moja”. W każdej mszy świętej dokonuje się cicha ofiara za całą ludzkość i za każdego z osobna. Jezus poucza siostrę Nastał, by dar Eucharystii, która niesie życie, był przez Nią przyjęty i by niosła to życie duszom bliźnim przez modlitwę, ofiarę i zapomnienie o sobie. Jezus ujawnia Jej tylko jedno swe oczekiwanie: „Pozwólcie, bym w was żył, jak żyję w Hostii”50.

\section{ZAKOŃCZENIE}

Doświadczenie duchowe s. Leonii Nastał ukazuje relację między Bogiem i człowiekiem, w której podmiot - człowiek podporządkowuje się przedmiotowi - Bogu. Bóg wybiera ludzi, czas i miejsce, aby objawić samego siebie. Tym doświadczeniem obecności obdarzył s. Leonię, wybrał ją, by mogła doświadczyć Jego miłości i dobroci, a następnie dzielić się tym z bliźnimi. Chrześcijańskie doświadczenie duchowe bazuje na integralnej wizji człowieka, dlatego celem działania Boga w doświadczeniu duchowym jest scalenie człowieka zarówno w tym, co duchowe, jak i w tym, co cielesne. Sługa Boża s. Leonia Nastał przez swoje doświadczenie duchowe pokazała, że można wejść w głębię osobistej relacji z Bogiem, ale też twórczo otworzyć się na świat, w którym żyjemy.

\section{L'ESPERIENZA SPIRITUALE CRISTIANA DELLA SERVA DI DIO LEONIA NASTAŁ}

\section{RIASSUNTO}

Nella dottrina teologia cristiana l'esperienza spiritualt e'un atto opur una Somma degli atti con la qualle uomo Si metee alla relazione di Dio. Al contrario dell'umana esperienza religiosa, la cristiana esperienza spirituale si attua per Cristo nella Chiesa.

L'autore affront ail tema: „La cristiana esperienza spirituale nella vita della Serva di Dio sour Leonia Nastał” nel suo Giornale spirituale. La sua esperienza spirituale ci monstra il rapporto tra Dio e l'uomo al quale soggetto - uomo si subordina al Dio. Lo scopo dell'azione di Dio e'quello: integrare l'uomo phisico e spirituale.

L'articole contiene i problemi: l'esperienza del Dio rivelante; l'esperienza di Cristo attraverso l'infanzia spirituale; gli atributi di Dio alla esperienza spirituale; l'esperienza spirituale nella chiesa.

\footnotetext{
${ }^{49}$ Zob. tamże, s. 89-90.

${ }^{50}$ Tamże, s. 152.
} 